Article

\title{
High-Titer Lactic Acid Production by Pediococcus acidilactici PA204 from Corn Stover through Fed-Batch Simultaneous Saccharification and Fermentation
}

\author{
Zhenting Zhang ${ }^{1}$, Yanan Li ${ }^{1}$, Jianguo Zhang ${ }^{1,2}$, Nan Peng ${ }^{1}$, Yunxiang Liang ${ }^{1}$ \\ and Shumiao Zhao ${ }^{1, *}$ \\ 1 State Key Laboratory of Agricultural Microbiology, College of Life Science and Technology, Huazhong \\ Agricultural University, Wuhan 430070, China; zhangzhenting@webmail.hzau.edu.cn (Z.Z.); \\ lana463936202@163.com (Y.L.); zhangjianguo@hfut.edu.cn (J.Z.); nanp@mail.hzau.edu.cn (N.P.); \\ fa-lyx@163.com (Y.L.) \\ 2 School of Food and Biological Engineering, Hefei University of Technology, Hefei 230009, China \\ * Correspondence: shumiaozhao@mail.hzau.edu.cn; Tel.: +86-27-8728-1267; Fax: +86-27-8728-0670
}

Received: 12 August 2020; Accepted: 22 September 2020; Published: 28 September 2020

\begin{abstract}
Lignocellulose comprised of cellulose and hemicellulose is one of the most abundant renewable feedstocks. Lactic acid bacteria have the ability to ferment sugar derived from lignocellulose. In this study, Pediococcus acidilactici PA204 is a lactic acid bacterium with a high tolerance of temperature and high-efficiency utilization of xylose. We developed a fed-batch simultaneous saccharification and fermentation (SSF) process at $37^{\circ} \mathrm{C}$ (pH 6.0) using the $30 \mathrm{FPU}$ (filter paper units)/g cellulase and $20 \mathrm{~g} / \mathrm{L}$ corn steep powder in a $5 \mathrm{~L}$ bioreactor to produce lactic acid (LA). The titer, yield, and productivity of LA produced from $12 \%(w / w) \mathrm{NaOH}$-pretreated and washed stover were $92.01 \mathrm{~g} / \mathrm{L}, 0.77 \mathrm{~g} / \mathrm{g}$ stover, and $1.28 \mathrm{~g} / \mathrm{L} / \mathrm{h}$, respectively, and those from $15 \% \mathrm{NaOH}$-pretreated and washed stover were $104.11 \mathrm{~g} / \mathrm{L}$, $0.69 \mathrm{~g} / \mathrm{g}$ stover, and $1.24 \mathrm{~g} / \mathrm{L} / \mathrm{h}$, respectively. This study develops a feasible fed-batch SSF process for LA production from corn stover and provides a promising candidate strain for high-titer and -yield lignocellulose-derived LA production.
\end{abstract}

Keywords: lactic acid fermentation; Pediococcus acidilactici PA204; simultaneous saccharification and fermentation; corn stover

\section{Introduction}

Lignocellulose, the most abundant global source of renewable biomass, is one of the most important raw materials for biofuel and biochemical production [1]. Corn stover, a lignocellulosic feedstock, is one of the most important agricultural residues available in high quantities with about 900 million tons produced in 2018 in China according to Ministry of Agriculture and Rural Affairs. Many studies have examined corn stover applied in different fields, such as generating electricity [2], biofuel [3] and biochemical production [4], and biological feed [5]. Especially, lactic acid (LA) is an important commodity chemical and also a monomer compound to produce biodegradable and biocompatible polylactic acid (PLA), which provides a sustainable alternative to petroleum-derived products [6]. The corn stover usually contains $37.5 \%$ cellulose, $22.4 \%$ hemicellulose, and $17.6 \%$ lignin, which can be hydrolyzed into hexose and pentose for fermentation [7].

However, lignocellulose hydrolysis and utilization remain considerable challenges in lignocellulose-derived biofuel and biochemical production [8]. At present, the main obstacles include lignocellulose pretreatment and hydrolysis, as well as the efficient fermentation of pentose derived 
from lignocellulosic hydrolysates into LA. Many studies have evaluated lignocellulose degradation and biofuel and biochemical production by using physical $[9,10]$, chemical, and biological [8] pre-treatments. Chemical methods are the most common pretreatment methods, including acid treatment, alkaline treatment, alkaline/oxidative treatment, wet oxidation, and ozonolysis [11-13]. Xylose limits the conversion from the hydrolysate of lignocellulose into LA [14]. Therefore, it is necessary to isolate or construct the strains that can efficiently utilize pentose. Several lactic acid bacteria (LAB) such as Lactobacillus pentosus [4], Lactobacillus brevis [15], Enterococcus mundtii QU 25 [16], and Enterococcus faceium QU 50 [17] have been reported to ferment xylose via the phosphoketolase pathway (hetero-fermentation pathway). Recently, including Lactobacillus strains $[4,15,18]$, Bacillus coagulans [12,19-21], and Pediococcus acidilactici [22,23], they have also been reported to produce high-titer LA from lignocellulosic materials. These strains with robust inhibition tolerance were found to be suitable for lignocellulose-derived LA production and were engineered for chemical production because of their thermophilic growth characteristics (except Lactobacillus strains) and strong pentose homofermentative activity.

Acid-pretreatment methods were used to efficiently produce LA. LA yield and titer produced from oil palm empty fruit bunch (OPEFB) acid hydrolysate reached $0.97 \mathrm{~g} / \mathrm{g}$ and $59.2 \mathrm{~g} / \mathrm{L}$ through B. coagulans fermentation, respectively [24]. LA yield and titer obtained from acid-pretreated wheat stover reached $0.46 \mathrm{~g} / \mathrm{g}$ (wheat stover) and $38.73 \mathrm{~g} / \mathrm{L}$, respectively, via B. coagulans IPE22 fermentation [20]. Excellent LA production was obtained from sulfuric acid-pretreated and biodetoxified corn stover through Pediococcus acidilactici DQ2 fermentation [25] with a good LA titer of $101.9 \mathrm{~g} / \mathrm{L}$ and poor yield of a mere $0.38 \mathrm{~g} / \mathrm{g}$ stover as P. acidilactici DQ2 cannot utilize xylose. A high titer $(104.4 \mathrm{~g} / \mathrm{L})$ of L-LA was obtained from dilute acid-pretreated and biodetoxified corn stover through an engineered P. acidilactici TY112 (CGMCC 8664) strain fermentation, and the yield of L-LA reached $0.72 \mathrm{~g} / \mathrm{g}$ glucose from total corn stover regardless of xylose unavailability [26]. However, the acid-pretreated method can lead to hemicellulose loss and cannot efficiently remove lignin $[27,28]$. Based on this, alkali-pretreated methods were exploited and applied. In our previous studies, B. coagulans LA204 and L. pentosus FL0421 could efficiently utilize corn stover and corncob to produce LA $[4,12,13]$. By using $\mathrm{NaOH}$-pretreated and washed corn stover, the LA yield and titer increased to $0.68 \mathrm{~g} / \mathrm{g}$ substrate and $97.6 \mathrm{~g} / \mathrm{L}$, respectively, through B. coagulans LA204 fed-batch fermentation [12]. The LA yield and titer obtained from alkali-pretreated corn stover reached $0.66 \mathrm{~g} / \mathrm{g}$ corn stover and $92.3 \mathrm{~g} / \mathrm{L}$, respectively, via L. pentosus FL0421 simultaneous saccharification and fermentation (SSF) [4]. By using B. coagulans LA204 fed-batch fermentation, the lactic acid titer and yield produced from $16 \%(w / w) \mathrm{NaOH}$-pretreated corncob were $122.99 \mathrm{~g} / \mathrm{L}$ and $0.77 \mathrm{~g} / \mathrm{g}$, respectively, and those produced from $16 \% \mathrm{NH}_{3}-\mathrm{H}_{2} \mathrm{O}_{2}$-pretreated and washed corncob were $118.60 \mathrm{~g} / \mathrm{L}$ and $0.74 \mathrm{~g} / \mathrm{g}$ corncob, respectively [13].

Pediococcus acidilactici PA204 with high temperature tolerance $\left(32-47^{\circ} \mathrm{C}\right)$ and efficient xylose conversion into lactic acid was used for high titer lactic acid production at the high solids loading of corn stover through the simultaneous saccharification and fermentation (SSF). As probiotics, P. acidilactici PA204 produces bacteriocin, which has a good inhibitory effect on some pathogenic microorganisms in the intestinal tract [29]. Additionally, this strain has long been announced to be safe as a probiotic strain that can be used in food and drugs by the food and drug administration (FDA) [30].

In this study, we developed a fed-batch SSF process for LA production using corn stover as a carbon source through P. acidilactici PA204 fermentation, and found that this strain produced LA from $12 \%$ ( $w / w$ loading) $\mathrm{NaOH}$-pretreated and washed corn stover with a titer of $92.01 \mathrm{~g} / \mathrm{L}$ and yield of $0.77 \mathrm{~g} / \mathrm{g}$ stover. It also produced acetic acid from the same corn stover with a titer of $10.03 \mathrm{~g} / \mathrm{L}$ and yield of $0.08 \mathrm{~g} / \mathrm{g}$ stover under nonsterile conditions. Our results provide a practical process for lactic acid production from lignocellulose residues. This study reveals that $P$. acidilactici PA204 is a promising candidate strain for high-yield and -titer lignocellulose-derived LA production. 


\section{Materials and Methods}

\subsection{Raw Materials and Enzyme}

Corn stover was grown in the Northeast of China and harvested in the autumn of 2016. After harvesting, corn stover was cleaned, dried, and sieved with the 80-mesh and pretreated at $75{ }^{\circ} \mathrm{C}$ for $3 \mathrm{~h}$ with $5 \%$ sodium hydroxide $(\mathrm{NaOH})$ at a $20 \%(w / w)$ loading. The resultant slurry was washed with water until the $\mathrm{pH}$ decreased to 8.0, and then filtered to a moisture content of $20 \%(w / w)$. The raw corn stover consisted of $37.12 \pm 0.32$ cellulose, $29.60 \pm 0.26$ hemicellulose, and $20.80 \pm 0.56$ lignin. The pretreated corn stover contained $51.34 \pm 0.57$ cellulose, $27.20 \pm 0.34$ hemicellulose, and $8.31 \pm 0.89$ lignin. The pretreated and washed corn stover contained $60.01 \pm 0.51$ cellulose, $27.33 \pm 0.21$ hemicellulose, and $6.87 \pm 0.66$ lignin. The cellulase used in this study was Cellic CTec2 (Novozymes, Denmark) containing cellulase, $\beta$-glucosidase, and xylanase, with its cellulose activity of 250 filter paper units (FPU)/mL.

\subsection{Medium and Strain}

The De Man-Rogosa-Sharpe (MRS) medium was used for seed culturing. MRS medium contained $10 \mathrm{~g}$ of peptone, $10 \mathrm{~g}$ of beef extract, $5 \mathrm{~g}$ of yeast extract, $20 \mathrm{~g}$ of dextrose, $5 \mathrm{~g}$ of sodium acetate trihydrate, $1 \mathrm{~g}$ of polysorbate 80, $2 \mathrm{~g}$ of dipotassium phosphate, $2 \mathrm{~g}$ of triammonium citrate, $0.25 \mathrm{~g}$ of magnesium sulfate heptahydrate, and $0.05 \mathrm{~g}$ of manganese sulfate tetrahydrate in $1 \mathrm{~L}$ deionized water [31]. The medium and water were autoclaved at $115^{\circ} \mathrm{C}$ for $20 \mathrm{~min}$. Pediococcus acidilactici PA204 was isolated and stored in our laboratory. Activation cultures were carried out in MRS medium at $37^{\circ} \mathrm{C}$ for $24 \mathrm{~h}$.

\subsection{Simultaneous Sacharification and Fermentation (SSF), and NaOH-Pretreated Corn Stover}

The mixture of $4 \% \mathrm{NaOH}$-pretreated and washed corn stover, $20 \mathrm{~g} / \mathrm{L}$ corn steep powder, and cellulase at a concentration of $30 \mathrm{FPU} / \mathrm{g}$ stover was inoculated with $200 \mathrm{~mL}$ seed culture to establish the SSF process in a $2 \mathrm{~L}$ volume. Fermentation was carried out at $37^{\circ} \mathrm{C}$ for $60 \mathrm{~h}$ with agitation at $150 \mathrm{rpm}$. The $\mathrm{pH}$ was maintained at 6.0 by automatic feeding of $10 \mathrm{M} \mathrm{NaOH}$ solution.

Fed-batch fermentations were performed with $8 \%$ pretreated and washed corn stover, a cellulase concentration of $30 \mathrm{FPU} / \mathrm{g}$ stover, $20 \mathrm{~g} / \mathrm{L}$ corn steep powder, and $200 \mathrm{~mL}$ seed culture (v/v) in a total volume of $2 \mathrm{~L}$. During fermentation, the washed corn stover was continuously fed at $24 \mathrm{~h}$, and the final concentration of pretreated and washed corn stover reached $12 \%(w / w)$ or $15 \%(w / w)$ and total fermentation volume reached approximately 3 L. Enzyme feeding for all fermentations is illustrated in Figure 3 with the final enzyme concentration of 30 FPU/g stover. Samples were collected every 6 or $12 \mathrm{~h}$. The concentrations of LA, acetic acid, glucose, and xylose were determined by HPLC. The fed corn stover was not sterilized.

\subsection{Analysis of Sugars, Acids, and Biomass}

Glucose, xylose, LA, acetic acid, and formic acid were analyzed using an Agilent 1200 HPLC system equipped with an RID-10A detector or an SPD-20A detector, and a Bio-Rad Aminex HPX-87H column with a column temperature of $40{ }^{\circ} \mathrm{C}$. The mobile phase was $5 \mathrm{mM} \mathrm{H}_{2} \mathrm{SO}_{4}$, and the flow rate was set as $0.6 \mathrm{~mL} / \mathrm{min}$. The LA yield was defined as the produced LA (g) per total sugar or total corn stover $(\mathrm{g})$. All samples were centrifuged and filtered through a $0.22 \mu \mathrm{m}$ membrane prior to loading. The strain biomass was counted by the dilution plate method.

\section{Results and Discussion}

\subsection{Effects of Temperature, $p H$, Carbon Source, and Nitrogen Source on LA Production}

P. acidilactici PA204, which can efficiently utilize glucose to produce lactic acid, was isolated and stored in the Fermentation Engineering Laboratory at Huazhong Agriculture University. In this study, the fermentation abilities of P. acidilactici PA204 to glucose, xylose, and xylobiose were tested in flasks. 
The sugar consumptions of glucose, xylose, and xylobiose media reached $94 \%, 86 \%$, and $55 \%$ in $10 \mathrm{~g} / \mathrm{L}$ sugar concentration, respectively. We found that the cell count in the glucose media was higher than those of other sugars (Figure 1A). These results suggested that P. acidilactici PA204 might have a strong ability to ferment lignocellulosic hydrolysates (glucose and xylose) into LA. We further examined the effect of temperature on P. acidilactici PA204 LA fermentation in glucose media. As shown in Figure 1B, the maximum LA yields ( 0.97 and $0.98 \mathrm{~g} / \mathrm{g}$ sugar) were achieved at $37^{\circ} \mathrm{C}$ and $42{ }^{\circ} \mathrm{C}$, respectively, while lower yields were found at other temperatures. The value of OD600 reached the highest (5.82 and 5.52) at $37{ }^{\circ} \mathrm{C}$ and $42{ }^{\circ} \mathrm{C}$, respectively. However, at $57^{\circ} \mathrm{C}$, the value of OD600 was only 1.34; thus, lactic acid can barely be produced. The effect of initial $\mathrm{pH}$ values on LA fermentation was also examined. The results indicated that an initial $\mathrm{pH}$ of 6.0 was optimal for lactic acid fermentation by this strain. As can be seen from Figure 1C, a higher LA titer was obtained at pH $6.0(9.74 \mathrm{~g} / \mathrm{L}$ vs. $10.27 \mathrm{~g} / \mathrm{L}, \mathrm{pH} 5.0$ vs. 6.0). In addition, the effect of nitrogen source concentration on LA fermentation was examined with $10 \mathrm{~g} / \mathrm{L}$ glucose as the carbon source and different concentrations of corn steep powder as the nitrogen source (Figure 1D). The results indicated that the highest LA concentration $(9.92 \mathrm{~g} / \mathrm{L}$ ) was produced from corn steep powder (at the concentration of $20 \mathrm{~g} / \mathrm{L}$ ) and that the cell count in the media containing 20 and $30 \mathrm{~g} / \mathrm{L}$ concentrations of corn steep powder was higher than that in other media, suggesting that the effects of nitrogen sources concentrations on lactic acid production efficiency coincided with those on cell growth efficiency. Moreover, the increase in nitrogen source concentration did not significantly affect the production of LA. These results indicated that corn steep powder can be used by P. acidilactici PA204 as an inexpensive nitrogen source for LA production and that the concentration of $20 \mathrm{~g} / \mathrm{L}$ can be determined as the optimal nitrogen source concentrations.

A

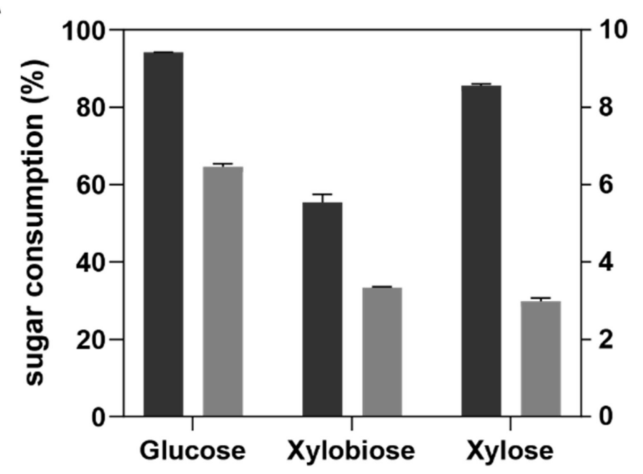

C

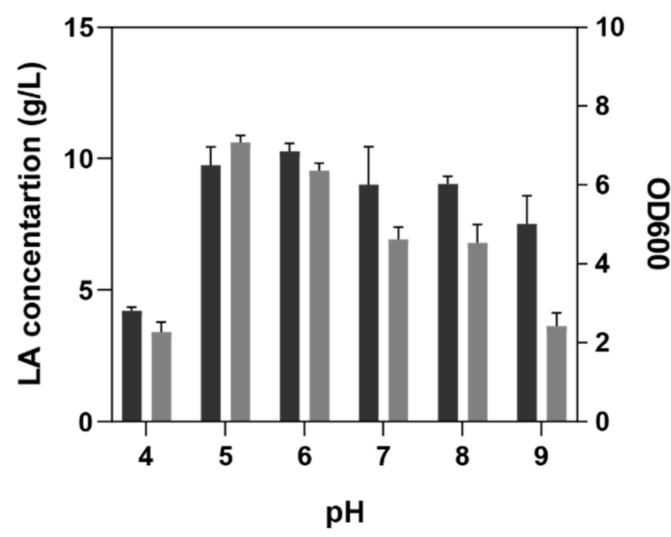

B

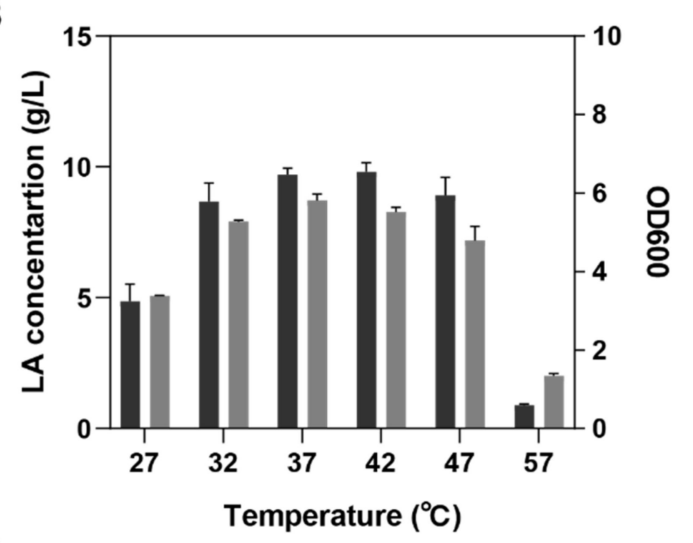

D

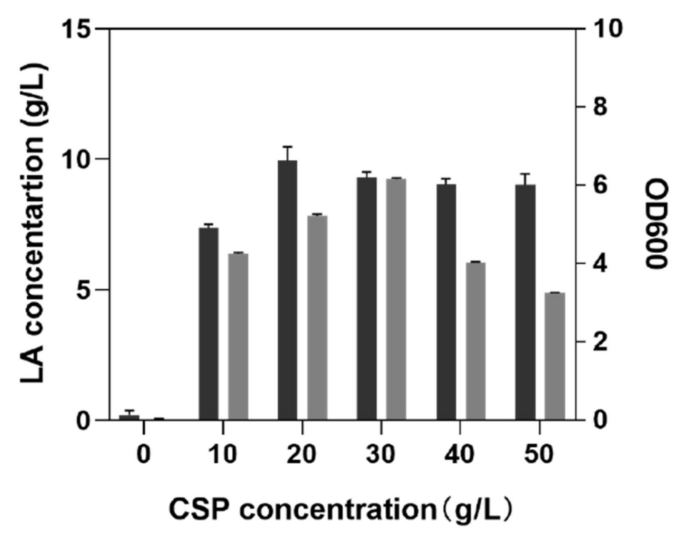

Figure 1. General features of P. acidilactici PA204 fermentation. (A) Lactic Acid (LA) production efficiency from glucose, xylose, and xylobiose media. Culture contains $10 \mathrm{~g} / \mathrm{L}$ of each sugar and $5 \mathrm{~g} / \mathrm{L}$ of 
yeast extract, $\mathrm{pH} 6.0$; fermentation was carried out at $37^{\circ} \mathrm{C}$. (B) Effect of temperature on LA fermentation. Culture contains $10 \mathrm{~g} / \mathrm{L}$ glucose and $5 \mathrm{~g} / \mathrm{L}$ yeast extract ( $\mathrm{pH}$ 6.0). (C) Effect of $\mathrm{pH}$ on LA fermentation. Culture contains $10 \mathrm{~g} / \mathrm{L}$ glucose and $5 \mathrm{~g} / \mathrm{L}$ yeast extract; fermentation was carried out at $37^{\circ} \mathrm{C}$. (D) Effect of CPS at different concentrations on LA production. CSP: Corn steep powder. Culture contains $10 \mathrm{~g} / \mathrm{L}$ glucose ( $\mathrm{pH}$ 6.0). Fermentation was carried out at $37^{\circ} \mathrm{C}$. Black bars: Sugar consumption efficiency and LA concentration; gray bars: OD600.

\subsection{High-Titer and High-Yield LA Production from NaOH-Pretreated Corn Stover through SSF}

$\mathrm{NaOH}$ pretreatment was reported to be an efficient method to remove lignin and destroy the structure of lignocellulose in our previous studies [12]. In this study, we selected $\mathrm{NaOH}$ pretreatment to remove lignin from corn stover and determined the compositional changes of corn stover before and after $\mathrm{NaOH}$ pretreatments. The higher the solubilization and reduction of lignin, the greater the cellulose composition increase of pre-treated corn stover [28]. As shown in Table 1, the solid fraction from $\mathrm{NaOH}$ pre-treated and washed corn stover showed a significant $61.66 \%$ increase in cellulose composition due to the sharp $66.97 \%$ decline in the percentage of lignin, and a lower marked $7.67 \%$ decrease in hemicellulose composition. The results indicated that $\mathrm{NaOH}$ pretreatment is an efficient method to remove lignin and retain cellulose and hemicellulose.

Table 1. The composition of different corn stover in this study. A: Raw corn stover. B: $\mathrm{NaOH}$ pre-treated corn stover. $\mathrm{C}$ : $\mathrm{NaOH}$ pre-treated corn stover and washed corn stover.

\begin{tabular}{cccc}
\hline Corn Stover & Cellulose (\%) & Hemicellulose (\%) & Lignin (\%) \\
\hline A & $37.12 \pm 0.32$ & $29.60 \pm 0.26$ & $20.80 \pm 0.56$ \\
B & $51.34 \pm 0.57$ & $27.20 \pm 0.34$ & $8.31 \pm 0.89$ \\
C & $60.01 \pm 0.51$ & $27.33 \pm 0.21$ & $6.87 \pm 0.66$ \\
\hline
\end{tabular}

In the initial SSF experiment, $4 \%(w / w) \mathrm{NaOH}$-pretreated and washed corn stover and $20 \mathrm{~g} / \mathrm{L}$ corn steep powder were the carbon source and nitrogen source, respectively. Cellulase was added at the beginning of fermentation, and the final enzyme concentration used was $30 \mathrm{FPU} / \mathrm{g}$ stover. The $10 \mathrm{M} \mathrm{NaOH}$ solution was used as the neutralizer. Initially, LA was produced rapidly. At hour 6 during fermentation, the LA titer reached $15.35 \mathrm{~g} / \mathrm{L}$, and the productivity reached $2.59 \mathrm{~g} / \mathrm{L} / \mathrm{h}$ (Figure 2), suggesting that for the first $6 \mathrm{~h}$, corn stover rapidly degraded by cellulase and xylanase into glucose and xylose. Then, P. acidilactici PA204 quickly utilized sugar to produce LA. However, at hour 48 during fermentation, the LA titer reached $25.92 \mathrm{~g} / \mathrm{L}$, the yield reached $0.65 \mathrm{~g} / \mathrm{g}$ stover, and the average productivity was $0.54 \mathrm{~g} / \mathrm{L} / \mathrm{h}$ (Table 2). The average productivity at hour 48 was significantly lower than that at the early fermentation stage. At hour 33 during fermentation, glucose and xylose were hardly detected and no significant increase in LA titer was observed from hour $33(25.48 \mathrm{~g} / \mathrm{L})$ to hour $48(25.92 \mathrm{~g} / \mathrm{L})$. During fermentation, the amounts of bacteria was gradually increased, and reached $9.1 \times 10^{9} \mathrm{cfu} / \mathrm{mL}$ at hour 27. After that, the increase in bacterium count tended to be stable, indicating the end of fermentation.

Table 2. Summary of lactic acid fermentation by P. acidilactici PA204 using $\mathrm{NaOH}$-pretreated and washed corn stover with washing as the carbon source. $4 \%$ stover: Simultaneous saccharification and fermentation (SSF) batch experiment. $12 \%$ and $15 \%$ stover: Fed-batch experiments.

\begin{tabular}{cccc}
\hline Experiments & $\mathbf{4 \%}$ Stover & $\mathbf{1 2} \%$ Stover & $\mathbf{1 5 \%}$ Stover \\
\hline Lactic acid titer $(\mathrm{g} / \mathrm{L})$ & 25.92 & 92.01 & 104.11 \\
Lactic acid yield $(\mathrm{g} / \mathrm{g}$ stover) & 0.65 & 0.77 & 0.69 \\
Lactic acid productivity (g/L/h) & 0.54 & 1.28 & 1.24 \\
Acetic acid titer $(\mathrm{g} / \mathrm{L})$ & 6.57 & 10.03 & 10.28 \\
Acetic acid yield $(\mathrm{g} / \mathrm{g}$ stover) & 0.16 & 0.08 & 0.07 \\
Acetic acid productivity $(\mathrm{g} / \mathrm{L} / \mathrm{h})$ & 0.14 & 0.14 & 0.12 \\
\hline
\end{tabular}




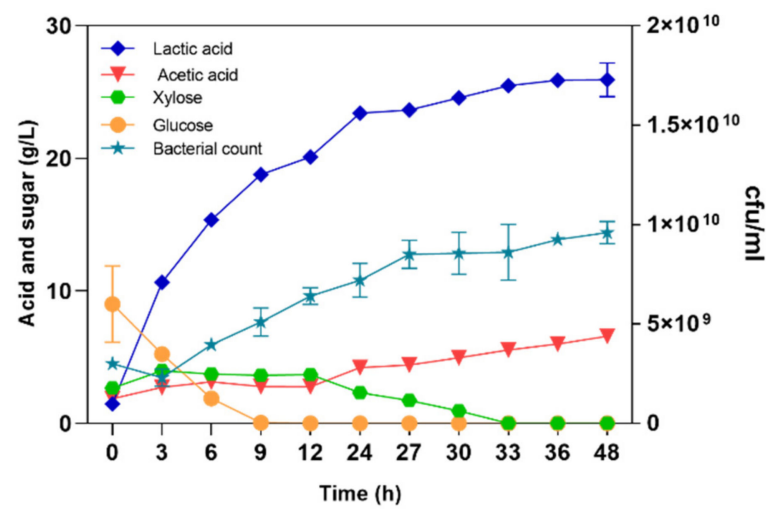

Figure 2. Lactic acid production from $\mathrm{NaOH}$-pretreated and washed corn stover $(4 \% w / w)$. The final cellulase concentration was $30 \mathrm{FPU} / \mathrm{g}$ stover. Diamonds indicate lactic acid. Inverted triangles represent acetic acid. Dots indicate glucose. Polygons represent xylose. Pentacle represent bacterial count. The three fermentation stages are presented in the figures.

\subsection{High-Titer and High-Yield LA Production through Fed-Batch Fermentation}

A good LA yield was obtained from $4 \%(w / w) \mathrm{NaOH}$-pretreated and washed corn stover, but the LA titer was not sufficient. Thus, a high solid loading of lignocellulosic materials was necessary to increase the LA titer. Considering the substance inhibition effect, the fed-batch experiment was carried out to increase the LA titer and yield. In two fed-batch experiments, $8 \%(w / w) \mathrm{NaOH}$-pretreated and washed corn stover (total of $2 \mathrm{~L}$ ) was inoculated with $10 \%$ seed culture and supplemented with $30 \mathrm{FPU} / \mathrm{g}$ of the cellulase solution. At hour 24 during fermentation, the pretreated and washed corn stover was continuously fed to reach the final corn stover concentration of $12 \%(w / w)$ or $15 \%(w / w)$, and the enzyme was fed to reach the final enzyme concentration of $30 \mathrm{FPU} / \mathrm{g}$ stover (Figure 3). Finally, the titers of LA produced from high solid loadings of $\mathrm{NaOH}$-pretreated and washed corn stover were tested. As Figure 3A shows, the LA yield from $12 \%$ solid loading reached $(w / w) 0.77 \mathrm{~g} / \mathrm{g}$ stover, LA titer reached $92.01 \mathrm{~g} / \mathrm{L}$, and the average productivity was $1.28 \mathrm{~g} / \mathrm{L} / \mathrm{h}$. The acetic acid titer reached $10.03 \mathrm{~g} / \mathrm{L}$ and its yield was $0.08 \mathrm{~g} / \mathrm{g}$ stover (Table 2). However, the LA yield from $15 \%$ solid loading $(w / w)$ reached $0.69 \mathrm{~g} / \mathrm{g}$ stover, the titer reached $104.11 \mathrm{~g} / \mathrm{L}$, and the average productivity was $1.24 \mathrm{~g} / \mathrm{L} / \mathrm{h}$ (Figure 3B). The acetic acid titer reached $10.28 \mathrm{~g} / \mathrm{L}$ and its yield was $0.07 \mathrm{~g} / \mathrm{g}$ stover (Table 2).

Three basic stages were identified in the LA fed-batch fermentation process using corn stover as the substrate (Figure 3). During the first stage (0-12 h), LA was quickly produced in all two experiments, and during this period, the productivity was $3.05 \mathrm{~g} / \mathrm{L} / \mathrm{h}(12 \% w / w$ loading, Figure $3 \mathrm{~A})$, and $3.90 \mathrm{~g} / \mathrm{L} / \mathrm{h}$ $(15 \% w / w$ loading, Figure 3B), respectively. These results indicated that LA productivity was dependent on the concentration of corn stover ( $8 \% w / w$ loading) at this stage. Therefore, both glucose and xylose were rapidly released, and then consumed (Figure 3$)$. During the second stage (12-36 h) at $12 \% w / w$ corn stover loading (Figure $3 \mathrm{~A}$ ), LA production slowed down before being fed with corn stover $(1.01 \mathrm{~g} / \mathrm{L} / \mathrm{h}, 12-24 \mathrm{~h})$. However, after being fed with stover and enzyme, LA significantly increased $(1.69 \mathrm{~g} / \mathrm{L} / \mathrm{h}, 24-36 \mathrm{~h})$. Similarly, during the second stage $(12-36 \mathrm{~h})$ at $15 \% \mathrm{w} / \mathrm{w}$ corn stover loading (Figure 3B), LA production slowed down before corn stover feeding $(1.04 \mathrm{~g} / \mathrm{L} / \mathrm{h}, 12-24 \mathrm{~h})$ and LA increased $(1.15 \mathrm{~g} / \mathrm{L} / \mathrm{h}, 24-36 \mathrm{~h})$ after stover and enzymes feeding. Interestingly, LA productivity at $12 \% w / w$ stover feeding was slightly higher than that at $15 \% w / w$ stover feeding $(1.69 \mathrm{~g} / \mathrm{L} / \mathrm{h}$ vs. $1.15 \mathrm{~g} / \mathrm{L} / \mathrm{h}$, Figure 3), indicating that LA productivity was dependent on the concentration of corn stover, and that the inhibitors in the corn stover might inhibit LA production [4]. The sugars consumption was observed. Glucose was found to be quickly released and consumed completely. However, xylose was accumulated and was not utilized fully at the end of fermentation (Figure 3). The result may be produced due to substrate inhibition. When a large amount of xylose was continuously released, it could not be consumed and utilized by P. acidilactici PA204 in time. Phenolic compounds in corn 
stover might inhibit utilization of xylose by P. acidilactici PA204. The underlying mechanism needed to be further investigated.

During the third stage ( $36 \mathrm{~h}$ to the end of fermentation), LA titer was increased continuously and slowly in fed-batch experiments, and significant differences in LA titer and productivity were observed between the $12 \% w / w$ feeding group $(92.01 \mathrm{~g} / \mathrm{L}$ and $0.634 \mathrm{~g} / \mathrm{L} / \mathrm{h})$ and $15 \% w / w$ feeding group $(104.11 \mathrm{~g} / \mathrm{L}$ and $0.646 \mathrm{~g} / \mathrm{L} / \mathrm{h})$. The glucose was consumed completely at hour 36 and xylose remained at a certain concentration until the end of fermentation $(5.29 \mathrm{~g} / \mathrm{L})$ in the $12 \% w / w$ feeding group (Figure $3 \mathrm{~A}$ ). However, in the $15 \% w / w$ feeding group, the glucose was consumed completely at hour 60 and xylose remained at the concentration of $9.66 \mathrm{~g} / \mathrm{L}$ (Figure 3B). Although the concentration of lactic acid was increased, lactic acid yield was slightly decreased. These results suggested that a high solid loading of corn stover could release more sugars and increase the yield of lactic acid to some extent. However, a high solid loading caused the delayed consumption of glucose and retention of more xylose. The possible reason might lie in that more pretreated corn stover might result in more inhibitors, as well as a substrate effect.

As shown in Table 2, the LA titer, yield, and productivity at $12 \%(w / w) \mathrm{NaOH}$-pretreated and washed corn stover feeding were $92.01 \mathrm{~g} / \mathrm{L}, 0.77 \mathrm{~g} / \mathrm{g}$ stover, and $1.28 \mathrm{~g} / \mathrm{L} / \mathrm{h}$, respectively, and at $15 \%(w / w)$ $\mathrm{NaOH}$-pretreated and washed stover feeding, they were $104.11 \mathrm{~g} / \mathrm{L}, 0.69 \mathrm{~g} / \mathrm{g}$ stover, and $1.24 \mathrm{~g} / \mathrm{L} / \mathrm{h}$, respectively. Generally, the chemical pretreatment method could induce inhibitors generation, whereas the washing method could obviously reduce the inhibitor concentration and improve LA production. However, the major disadvantage of the washing method is the substantial volume of waste washing water generated by inhibitor removal. In the industrial production process, wastewater should be strictly limited because of the high cost of wastewater treatment. Therefore, other methods including biological detoxification, pretreatment with few inhibitors, and screening of inhibitor-tolerant strains need to be developed in order to increase the LA titer and yield by using unwashed pretreated corn stover.

A

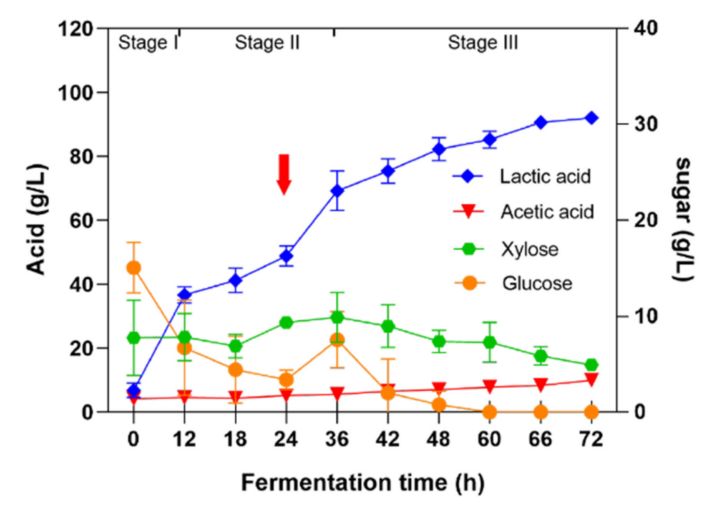

B

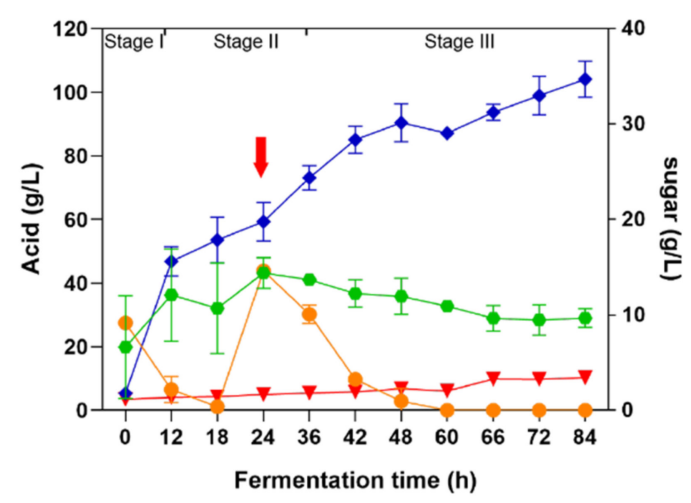

Figure 3. Lactic acid production from $\mathrm{NaOH}$-pretreated and washed corn stover. (A) Initial $8 \%(w / w)$ $\mathrm{NaOH}$-pretreated and washed corn stover was fed with the stover treated in the same manner at hour 24 to reach the final concentration of $12.0 \%(w / w)$. (B) Initial $8 \%(w / w) \mathrm{NaOH}$-pretreated and washed corn stover was fed with the stover treated in the same manner at hour 24 to reach the final concentration of $15.0 \%(w / w)$. Substrate and enzyme feedings are indicated by red arrows. The final cellulase concentration in both experiments was $30 \mathrm{FPU} / \mathrm{g}$ stover. Diamonds indicate lactic acid. Inverted triangles represent acetic acid. Dots indicate glucose. Polygons represent xylose. The three fermentation stages are presented in the figures.

\section{Conclusions}

In this study, we produced high-titer and high-yield LA from $\mathrm{NaOH}$-pretreated and washed corn stover through P. acidilactici PA204 fermentation. Importantly, P. acidilactici PA204 was found to 
specifically ferment xylose to produce lactic acid. An efficient SSF fed-batch process for LA production from $\mathrm{NaOH}$-pretreated and washed corn stover by P. acidilactici PA204 has been established at $37^{\circ} \mathrm{C}$ and $\mathrm{pH} 6.0$ with a cellulase activity of $30 \mathrm{FPU} / \mathrm{g}$ stover and $20 \mathrm{~g} / \mathrm{L}$ corn steep powder in a $5 \mathrm{~L}$ bioreactor. The lactic acid titer, yield, and productivity were $92.01 \mathrm{~g} / \mathrm{L}, 0.77 \mathrm{~g} / \mathrm{g}$ stover, and $1.28 \mathrm{~g} / \mathrm{L} / \mathrm{h}$ at $12 \%(w / w) \mathrm{NaOH}$-pretreated and washed stover feeding, respectively, and they were $104.11 \mathrm{~g} / \mathrm{L}$, $0.69 \mathrm{~g} / \mathrm{g}$ corncob, and $1.24 \mathrm{~g} / \mathrm{L} / \mathrm{h}$ at $15 \% \mathrm{NaOH}$-pretreated and washed stover feeding, respectively. What is more, fermentation without sterilization has advantages in reducing production cost and energy consumption. This study develops a feasible fed-batch SSF process for LA production from corn stover and provides a promising candidate strain for high-titer and -yield lignocellulose-derived LA production.

Author Contributions: Conceptualization, S.Z., J.Z., N.P. and Y.L. (Yunxiang Liang); methodology, Z.Z. and Y.L. (Yanan Li); formal analysis, Z.Z.; data curation, Z.Z. and Y.L. (Yanan Li); writing—original draft preparation, Z.Z.; writing-review and editing, S.Z.; visualization, Z.Z.; supervision, S.Z.; project administration, S.Z. and J.Z.; funding acquisition, S.Z. and J.Z. All authors have read and agreed to the published version of the manuscript.

Funding: This work was supported by the Fundamental Research Funds for the Central Universities (No. 2662018JC016) and State Key Laboratory of Agricultural Microbiology (grant AMLKF201808).

Conflicts of Interest: The authors declare no conflict of interest.

\section{References}

1. Lin, Y.; Tanaka, S. Ethanol fermentation from biomass resources: Current state and prospects. Appl. Microbiol. Biotechnol. 2006, 69, 627-642. [CrossRef] [PubMed]

2. Wang, X.; Feng, Y.; Wang, H.; Qu, Y.; Yu, Y.; Ren, N.; Li, N.; Wang, E.; Lee, H.; Logan, B.E. Bioaugmentation for Electricity Generation from Com Stover Biomass Using Microbial Fuel Cells. Environ. Sci. Technol. 2009, 43, 6088-6093. [CrossRef] [PubMed]

3. Chen, S.; Xu, Z.; Li, X.; Yu, J.; Cai, M. Integrated bioethanol production from mixtures of corn and corn stover. Bioresour. Technol. 2018, 258, 18-25. [CrossRef] [PubMed]

4. Hu, J.; Lin, Y.; Zhang, Z.; Xiang, T.; Mei, Y.; Zhao, S.; Liang, Y.; Peng, N. High-titer lactic acid production by Lactobacillus pentosus FL0421 from corn stover using fed-batch simultaneous saccharification and fermentation. Bioresour. Technol. 2016, 214, 74-80. [CrossRef] [PubMed]

5. Li, Y.; Xu, F.; Li, Y.; Lu, J.; Li, S.; Shah, A.; Zhang, X.; Zhang, H.; Gong, X.; Li, G. Reactor performance and energy analysis of solid state anaerobic co-digestion of dairy manure with corn stover and tomato residues. Waste Manag. 2018, 73, 130-139. [CrossRef]

6. Abdel-Rahman, M.A.; Tashiro, Y.; Sonomoto, K. Recent advances in lactic acid production by microbial fermentation processes. Biotechnol. Adv. 2013, 31, 877-902. [CrossRef]

7. Zhu, Y.; Lee, Y.Y.; Elander, R.T. Conversion of aqueous ammonia-treated corn stover to lactic acid by simultaneous saccharification and cofermentation. Appl. Microbiol. Biotechnol. 2007, 136, 721-738.

8. Li, Y.; Lei, L.; Zheng, L.; Xiao, X.; Tang, H.; Luo, C. Genome sequencing of gut symbiotic Bacillus velezensis LC1 for bioethanol production from bamboo shoots. Biotechnol. Biofuels 2020, 13, 34. [CrossRef]

9. Zhang, J.; Shao, S.; Bao, J. Long term storage of dilute acid pretreated corn stover feedstock and ethanol fermentability evaluation. Bioresour. Technol. 2016, 201, 355-359. [CrossRef]

10. Talebnia, F.; Karakashev, D.; Angelidaki, I. Production of bioethanol from wheat straw: An overview on pretreatment, hydrolysis and fermentation. Bioresour. Technol. 2010, 101, 4744-4753. [CrossRef]

11. Lloyd, T.A.; Wyman, C.E. Combined sugar yields for dilute sulfuric acid pretreatment of corn stover followed by enzymatic hydrolysis of the remaining solids. Bioresour. Technol. 2005, 96, 1967-1977. [CrossRef] [PubMed]

12. Hu, J.; Zhang, Z.; Lin, Y.; Zhao, S.; Mei, Y.; Liang, Y.; Peng, N. High-titer lactic acid production from $\mathrm{NaOH}$-pretreated corn stover by Bacillus coagulans LA204 using fed-batch simultaneous saccharification and fermentation under non-sterile condition. Bioresour. Technol. 2015, 182, 251-257. [CrossRef] [PubMed]

13. Zhang, Z.; Xie, Y.; He, X.; Li, X.; Hu, J.; Ruan, Z.; Zhao, S.; Peng, N.; Liang, Y. Comparison of high-titer lactic acid fermentation from $\mathrm{NaOH}$ - and $\mathrm{NH}_{3}-\mathrm{H}_{2} \mathrm{O}_{2}$-pretreated corncob by Bacillus coagulans using simultaneous saccharification and fermentation. Sci. Rep. 2016, 6, 37245. [CrossRef] [PubMed] 
14. Daiana, W.; Arias, J.M.; Modesto, L.F.; de França Passos, D.; Pereira, N., Jr. Lactic acid production from sugarcane bagasse hydrolysates by Lactobacillus pentosus: Integrating xylose and glucose fermentation. Biotechnol. Prog. 2018, 35, e2718.

15. Zhang, Y.; Vadlani, P.V. Lactic acid production from biomass-derived sugars via co-fermentation of Lactobacillus brevis and Lactobacillus plantarum. J. Biosci. Bioeng. 2015, 119, 694-699. [CrossRef] [PubMed]

16. Abdel-Rahman, M.A.; Tashiro, Y.; Zendo, T.; Hanada, K.; Shibata, K.; Sonomoto, K. Efficient homofermentative L-(+)-lactic acid production from xylose by a novel lactic acid bacterium, Enterococcus mundtii QU 25. Appl. Environ. Microbiol. 2011, 77, 1892-1895. [CrossRef]

17. Abdel-Rahman, M.A.; Tashiro, Y.; Zendo, T.; Sakai, K.; Sonomoto, K. Enterococcus faecium QU 50: A novel thermophilic lactic acid bacterium for high-yield l-lactic acid production from xylose. FEMS Microbiol. Lett. 2015, 362, 1-7. [CrossRef]

18. Cui, F.; Li, Y.; Wan, C. Lactic acid production from corn stover using mixed cultures of Lactobacillus rhamnosus and Lactobacillus brevis. Bioresour. Technol. 2011, 102, 1831-1836. [CrossRef]

19. Bischoff, K.M.; Liu, S.; Hughes, S.R.; Rich, J.O. Fermentation of corn fiber hydrolysate to lactic acid by the moderate thermophile Bacillus coagulans. Biotechnol. Lett. 2010, 32, 823-828. [CrossRef]

20. Zhang, Y.; Chen, X.; Luo, J.; Qi, B.; Wan, Y. An efficient process for lactic acid production from wheat straw by a newly isolated Bacillus coagulans strain IPE22. Bioresour. Technol. 2014, 158, 396-399. [CrossRef]

21. Ye, L.; Hudari, M.S.; Zhou, X.; Zhang, D.; Li, Z.; Wu, J.C. Conversion of acid hydrolysate of oil palm empty fruit bunch to L-lactic acid by newly isolated Bacillus coagulans JI12. Appl. Microbiol. Biotechnol. 2013, 97, 4831-4838. [CrossRef] [PubMed]

22. Qiu, Z.; Gao, Q.; Bao, J. Engineering Pediococcus acidilactici with xylose assimilation pathway for high titer cellulosic 1-lactic acid fermentation. Bioresour. Technol. 2018, 249, 9-15. [CrossRef] [PubMed]

23. Qiu, Z.; Gao, Q.; Bao, J. Constructing xylose-assimilating pathways in Pediococcus acidilactici for high titer d-lactic acid fermentation from corn stover feedstock. Bioresour. Technol. 2017, 245, 1369-1376. [CrossRef] [PubMed]

24. Eom, I.Y.; Oh, Y.H.; Park, S.J.; Lee, S.H.; Yu, J.H. Fermentative 1-lactic acid production from pretreated whole slurry of oil palm trunk treated by hydrothermolysis and subsequent enzymatic hydrolysis. Bioresour. Technol. 2015, 185, 143-149. [CrossRef] [PubMed]

25. Zhao, K.; Qiao, Q.; Chu, D.; Gu, H.; Dao, T.H.; Zhang, J.; Bao, J. Simultaneous saccharification and high titer lactic acid fermentation of corn stover using a newly isolated lactic acid bacterium Pediococcus acidilactici DQ2. Bioresour. Technol. 2013, 135, 481-489. [CrossRef] [PubMed]

26. Yi, X.; Zhang, P.; Sun, J.; Tu, Y.; Gao, Q.; Zhang, J.; Bao, J. Engineering wild-type robust Pediococcus acidilactici strain for high titer L- and D-lactic acid production from corn stover feedstock. J. Biotechnol. 2015, 217, 112-121. [CrossRef] [PubMed]

27. Guo, P.; Mochidzuki, K.; Cheng, W.; Zhou, M.; Gao, H.; Zheng, D.; Wang, X.; Cui, Z. Effects of different pretreatment strategies on corn stalk acidogenic fermentation using a microbial consortium. Bioresour. Technol. 2011, 102, 7526-7531. [CrossRef]

28. Toquero, C.; Bolado, S. Effect of four pretreatments on enzymatic hydrolysis and ethanol fermentation of wheat straw. Influence of inhibitors and washing. Bioresour. Technol. 2014, 157, 68-76. [CrossRef]

29. Millette, M.; Dupont, C.; Shareck, F.; Ruiz, M.T.; Lacroix, M. Purification and identification of the pediocin produced by Pediococcus acidilactici MM33, a new human intestinal Strain. J. Appl. Microbiol. 2008, 104, 269-275.

30. Porto, M.C.; Kuniyoshi, T.M.; Azevedo, P.O.; Vitolo, M.; Oliveira, R.P. Pediococcus spp.: An important genus of lactic acid bacteria and pediocin producers. Biotechnol. Adv. 2017, 35, 361-374. [CrossRef]

31. De Man, J.C. Lactobacillus bulgaricus (Luerssen et Kuehn) Holland. Antonie Van Leeuwenhoek 1960, 26, 77-80. [CrossRef] [PubMed]

(C) 2020 by the authors. Licensee MDPI, Basel, Switzerland. This article is an open access article distributed under the terms and conditions of the Creative Commons Attribution (CC BY) license (http://creativecommons.org/licenses/by/4.0/). 